\title{
CROWDSOURCING W SEKTORZE PUBLICZNYM - MODEL PARTYCYPACJI SPOŁECZNEJ
}

\section{Abstract \\ Crowdsourcing in the public sector - a model of social participation}

This article is about the use of crowdsourcing in public sector. In many countries in the world, also in Poland, state authorities at various levels have sought effective ways to involve their citizens in public decision-making. The main objective of increasing civic engagement is to broadly promote trust in public authority activities and to build civil partnerships. The Polish experience in this area is not satisfactory and forces both practitioners and theorists to look for solutions that would achieve such goals. The author presents the model of key elements influencing the level of civic engagement.

Keywords: crowdsourcing, public management, social participation, key success factors

\section{Streszczenie}

Artykuł poświęcony jest tematyce zastosowania crowdsourcingu w przestrzeni publicznej. Od dawna w wielu krajach na świecie, również w Polsce, władze państwowe różnego szczebla szukają efektywnych sposobów włączenia obywateli, społeczności lokalnej w procesy podejmowania decyzji w sferze publicznej. Głównym celem tego typu inicjatyw jest szerokie promowanie zaufania do działań władzy publicznej oraz budowanie trwałych więzi społecznych. Polskie doświadczenia w tym zakresie nie są do końca satysfakcjonujące. Wdrażane inicjatywy oparte na partycypacji społecznej w sferze publicznej nie przynoszą oczekiwanych rezultatów. Często podejmowane inicjatywy, szczególnie popularny budżet obywatelski, mają charakter fasadowy. Celem artykułu jest przedstawienie modelu czynników kreujących zaangażowanie obywatelskie w przedsięwzięcia inicjowane przez władze publiczne, których realizacja oparta jest na koncepcji crowdsourcingu.

Słowa kluczowe: crowdsourcing, zarządzanie publiczne, partycypacja społeczna, krytyczne czynniki sukcesu 


\section{Wstęp}

Od co najmniej dwóch dekad obserwujemy intensywny rozwój społeczeństwa informacyjnego, które wykorzystując potężny instrument, jakim jest internet, buduje pozycję dodatkowego, wpływowego gracza w życiu społecznym, gospodarczym i politycznym. W sieci na licznych platformach uczestnictwa ich użytkownicy dzielą się swoimi spostrzeżeniami, opiniami i pomysłami. Przedstawiane uwagi, wskazówki i koncepcje są przedmiotem zainteresowania przedsiębiorców, władz publicznych i organizacji społecznych. Podmioty działające zarówno w sferze prywatnej, jak i publicznej coraz częściej odwołują się do doświadczenia i wiedzy, jaka tkwi w tłumie. Na umiejętnym wykorzystaniu mądrości tłumu opiera się koncepcja crowdsourcingu, która może dotyczyć różnych procesów, od zbierania opinii na temat obecnego i nowego produktu (usługi), przez kierowanie prośby o rozwiązanie konkretnego problemu, po szukanie kontrahentów, inwestorów, a nawet pracowników zainteresowanych partycypowaniem $\mathrm{w}$ danym projekcie. Tę różnorodność podejmowanych inicjatyw crowdosurcingowych potwierdza praktyka [Jain, 2010; Brabham, 2010]. Dialog ze społeczeństwem służy wzmocnieniu demokracji. W wielu krajach, Polska nie jest tu wyjątkiem, władze od lat próbuja zaangażować obywateli, by współdecydowali w sprawach dotyczących sfery publicznej. Ma to służyć przede wszystkim wzrostowi ich zaufania do działań władzy publicznej dzięki zwiększeniu przejrzystości stosowanych procedur. Dodatkowo aktywne partycypowanie obywateli w procesie zarządzania sprawami społeczności, której są członkami, buduje poczucie odpowiedzialności za rezultaty wspólnie podejmowanych decyzji. Aby zrealizować tak postawione cele crowdsourcingu w sferze publicznej, władze muszą tworzyć odpowiednie narzędzia i kanały komunikacji, dzięki którym obywatele mogą być rzeczywistym i konstruktywnym uczestnikiem życia publicznego.

Artykuł ma na celu zaprezentowanie modelu czynników, które kształtują poziom zaangażowania obywateli w projekty władz publicznych wykorzystujące crowdsourcing. W opracowaniu zastosowano metodę badań literaturowych i źródeł internetowych, a także metodę indukcyjną. Wskazano w nim krytyczne czynniki wpływające na poziom partycypacji społecznej. Czynniki te poddano analizie. Przedstawione treści pozwalają na sformułowanie ogólnych wniosków na temat skuteczności rozwiązań crowdsourcingowych inicjowanych przez władze publiczne w Polsce.

\section{Crowdsourcing — ramy teoretyczne koncepcji}

W zagranicznej literaturze przedmiotu można zapoznać się z licznymi definicjami crowdsourcingu, a samo wyrażenie czasami zastępowane jest określeniem typu co-creation, open-innovation czy citizen-sourcing, co może oznaczać, że sama koncepcja ewoluuje. Po raz pierwszy wyrażenia „crowdsourcing” użył Jeff 
Howe w 2006 roku, definiując je jako outsourcing zadań dotychczas wykonywanych przez wyspecjalizowanych dostawców (pracowników), kierowany do niezdefiniowanej, zazwyczaj dużej grupy ludzi w formie otwartego zaproszenia [Howe, 2006]. Kolejna ważna definicja prezentowanej koncepcji została przedstawiona przez Darena Brabhama, który określił crowdsourcing jako model rozwiązywania problemów i zadań wykorzystujący zbiorową inteligencję społeczności online, tak aby służyła określonym celom organizacji. Społeczność online, zwana tłumem, reaguje na inicjatywy crowdsourcingowe i jest zmotywowana do rozwiązywania problemów i realizacji zadań wskazanych przez organizacje [Brabham, 2013: 20]. Na uwagę, pod kątem ujęcia definicyjnego, zasługuje publikacja Enrique'a Estellésa-Arolasa i Fernanda Gonzáleza-Ladróna-de-Guevary [2012], w której przedstawili oni prawie 40 definicji crowdsourcingu, jakie pojawiły się w dotychczasowej literaturze przedmiotu. Dominuje wśród nich odniesienie do outsourcingu. Jest to popularna od wielu dekad koncepcja o zasięgu globalnym, która prowadzi do przekazywania pewnych zadań, działań poza strukturę organizacyjną jednostki - zewnętrznym wyspecjalizowanym dostawcom krajowym i zagranicznym [Arnold, 2000; McIvor, 2010; Marcinkowska, 2012]. Stąd teoretyczne założenia koncepcji outsourcingu są wykorzystywane w celu wyjaśnienia mechanizmu crowdsourcingu. Ten ostatni jest często definiowany jako outsourcing zadań i usług kierowany do dużej grupy ludzi zamiast do pracowników zatrudnionych w firmie lub do dostawców zewnętrznych.

W niniejszym artykule przyjęto definiować crowdsourcing jako koncepcję, w której organizacje, wykorzystując zaawansowane technologie informatyczne, zwracają się do wirtualnego tłumu w celu realizacji wybranych zadań lub rozwiązania określonych problemów. Organizacja (przedsiębiorstwo, instytucja, organizacja działająca w sferze publicznej, pozarządowa, non profit itp.) i wirtualny tłum współpracują ze sobą, osiągając obopólne korzyści, a do współpracy wykorzystują współczesne medium o globalnym zasięgu, jakim jest internet. Stopień złożoności zadania do rozwiązania determinuje dobór grupy, do której jest ono kierowane. Do realizacji prostych zadań angażuje się nieokreśloną grupę $\mathrm{z}$ wirtualnego tłumu, do zadań złożonych zaprasza się jasno zdefiniowaną grupę społeczności internetowych (klienci, użytkownicy, eksperci, specjaliści itd.).

Podsumowując, współpraca w ramach inicjatyw crowdsourcingowych:

- dotyczy jasno sprecyzowanych problemów i zadań organizacji, które ta kieruje do określonej bądź nieokreślonej grupy ludzi;

- opiera się na wykorzystaniu potencjału intelektualnego społeczności online;

- bazuje na dobrowolności udziału wirtualnego tłumu.

Mimo istotnej roli internetu w procesie crowdsourcingu warto zaznaczyć, że jego ideę można zrealizować również offline’ .

${ }^{1}$ Przykładem zastosowania crowdsourcingu offline jest przypadek Petera Jacksona, reżysera Władcy pierścieni, który przy realizacji drugiej części trylogii, Dwóch wież, potrzebował wykreować specyficzny dźwięk wydawany przez armię orków, i wówczas skierował swoją prośbę do fizycznego, a nie wirtualnego thumu. Na stadionie w Wellington w Nowej Zelandii zebrał się thum 20 tys. fanów krykieta, których krzyki i jęki stworzyły dźwięk do filmu [Prpić i in., 2015: 78]. 
Koncepcja crowdsourcingu opiera się na dzieleniu się przez członków społeczności online ich wiedzą, umiejętnościami i doświadczeniem. Dlaczego dzielą się oni swoją wiedzą i swoimi pomysłami z innymi, często nieodpłatnie, kosztem prywatnego, wolnego czasu? Wyjaśnieniu tego zjawiska służy teoria samodeterminacji Edwarda Deciego i Richarda Ryana, która motywację ludzi opiera na intencjonalności działania. Odwołuje się ona do wrodzonych potrzeb ludzi: potrzeby kompetencji, relacji i autonomii [Ryan, Deci, 2000]. Jeżeli te trzy potrzeby są zaspokojone, człowiek ma motywację do działania [Deci, Ryan, 1991]. Motywowanie polega na wpływaniu na innych tak, by poruszali się w pożądanym przez nas kierunku [Ryan, Deci, 2000: 54]. W kontekście crowdsourcingu wyróżnia się dwa typy motywacji: wewnętrzną i zewnętrzną [Brabham, 2012; Stewart i in., 2010]. Motywacja wewnętrzna prowadzi człowieka do podejmowania takich działań, które przynoszą mu korzyści niematerialne. Dzięki tego typu motywacji uczymy się, doskonalimy i rozwijamy. Jesteśmy w pełni, autonomicznie samozdeterminowani do działania. Motywacja wewnętrzna wyjaśnia naturalną potrzebę człowieka do asymilacji, spontanicznego zainteresowania czynnościami i odkrywania nowych obszarów czy zagadnień [Deci, Ryan, 1991]. Drugi typ motywacji stanowi motywacja zewnętrzna, która skłania człowieka do działania ze względu na możliwe nagrody, na prestiż czy chęć zyskania uznania w oczach innych. Podobne ujęcie motywacji zewnętrznej znajdziemy w determinizmie Thomasa Hobbesa. Według zwolenników behawioryzmu zachowanie człowieka jest determinowane przez środowisko zewnętrzne, a system nagród i kar decyduje o tym, w co się angażujemy, a czego unikamy [Skinner, 1953].

\section{Model krytycznych czynników sukcesu dla przedsięwzięć crowdsourcingowych inicjowanych przez władze publiczne}

Zwiększenie zaangażowania obywateli w procesy decyzyjne władz publicznych jest priorytetem współczesnej polityki, a koncepcja crowdsourcingu to odpowiednie narzędzie pozwalające taki cel osiągnąc [Brabham, 2009; Hilgers, Ihl, 2010]. Dzięki crowdsourcingowi można dotrzeć do szerokiej grupy odbiorców informacji i ułatwić prowadzenie dialogu między obywatelami a władzą publiczną [Bugs i in., 2010; Adams, 2011]. Partycypacja społeczna jest podstawą tworzenia społeczeństwa obywatelskiego. Zazwyczaj zaangażowanie obywatelskie nie jest procesem samoistnym, ale wykreowanym poprzez ukierunkowane, dobrze zaplanowane działania władz publicznych.

W sferze publicznej urzeczywistnieniem koncepcji crowdsourcingu są mechanizmy realizacji tzw. otwartych rządów (OR), budżetu partycypacyjnego, planowania przestrzennego, jak również pozostałe działania w sferze zarządzania społecznością lokalną. Wśród licznych inicjatyw władz publicznych na świecie i w Polsce wykorzystujących zjawisko crowdsourcingu coraz większą popularnością cieszy się wpisana w strategię e-government 2.0 koncepcja otwartych rządów. Sama koncepcja e-government 2.0 przez wykorzystanie narzędzi Web 2.0 
stara się włączać obywateli w proces zarządzania na poziomie państwa, miasta, dzielnicy czy osiedla. Strategia ta obejmuje działania związane z cyfryzacją administracji, ale jej clou stanowi zmiana sposobu myślenia o administracji. Dzięki tej strategii administracja staje się otwarta na implementowanie pomysłów pochodzących z jej otoczenia, a relacje między władzą a obywatelem nabierają charakteru partnerskiego. Realizacja koncepcji OR wykorzystuje założenia teoretyczne crowdsourcingu. Władze publiczne, używając platformy internetowej, definiują problemy i zadania kierowane do społeczności online, a następnie opinie i uwagi tej społeczności są analizowane i wykorzystywane zgodnie z nakreślonymi celami otwartych rządów. Współpraca ma charakter dobrowolny, przynosi korzyści zaangażowanym stronom. Liczne przykłady na świecie potwierdzają, że w praktyce koncepcja otwartych rządów jest często implementowana. Na przykład administracja prezydenta Obamy zbudowała platformę internetową, na której realizowano założenia koncepcji OR. Eksperci akademiccy, obywatele i pracownicy administracji rządowej prowadzili w internecie dialog, który służył dzieleniu się doświadczeniem i wypracowywaniu najlepszych praktyk w zarządzaniu publicznym. Zgromadzone opinie wykorzystywano w celu poprawy przejrzystości działań władz państwowych i budowania otwartości na nie [Open Government Initiative]. Również w Polsce, w 2010 roku, zainicjowano ideę otwartych rządów, przyjmując założenie, że swobodny dostęp do zasobów publicznych w sieci jest głównym narzędziem zwiększającym zaangażowanie obywateli w procesy zarządzania. We współpracy z organizacjami pozarządowymi i firmami prywatnymi wdrożono projekty, które mają realizować założenia otwartych rządów. Niestety w praktyce dostęp do informacji publicznej w Polsce jest nadal na niewystarczającym poziomie, ale bardziej niepokojące jest potwierdzone badaniami bardzo niskie zaangażowanie społeczne, którego zwiększenie jest głównym celem tej koncepcji [Młynarski i in., 2013].

Kolejną inicjatywą wpisującą się w koncepcję crowdsourcingu jest budżet obywatelski (partycypacyjny), którego mechanizm realizacji opiera się na wykorzystaniu podstawowych założeń tej koncepcji. Władza publiczna na poziomie lokalnym definiuje cele budżetu partycypacyjnego i sposób jego realizacji. Stosując zróżnicowane narzędzia komunikacji, kieruje zadanie, finansowane ze środków publicznych, do społeczności lokalnej. Społeczność ta przedstawia, a następnie głosuje na rozwiązania, które w założeniu powinny jak najlepiej służyć możliwie największej grupie reprezentującej daną społeczność.

Budżet partycypacyjny jest popularnym urzeczywistnieniem koncepcji crowdsourcingu. Często mówi się wręcz o panującej w Polsce modzie na budżety obywatelskie. Również i w przypadku tej inicjatywy trudno nazwać ją sukcesem. Mimo że wiele miast wdraża to rozwiązanie, najważniejsze założenia budżetu obywatelskiego nie są realizowane. Budżet partycypacyjny poza otwarciem się na społeczeństwo ma za zadanie doprowadzić do efektywnego wydawania pieniędzy publicznych i budowania trwałych więzi w społeczności lokalnej. Cele te nie są realizowane. Budżet obywatelski jest narzędziem o najwyższym poziomie partycypacji społecznej, a w polskich realiach przyjmuje często formę przeregulowanej procedury administracyjnej [Skrzypiec i in., 2016]. Jest to dowód braku zaufania do władz lokalnych, 
a bez zaufania nie da się budować otwartości i dobrej współpracy. W krajach, gdzie zaufanie mieszkańców do władz jest na wysokim poziomie, odnotowuje się zdecydowanie mniej inicjatyw tego typu. Przykładem jest Szwecja. Władze publiczne tego kraju od dawna prowadziły politykę jawności i otwartości. Budżet obywatelski wdrożony został jedynie w kilku gminach, a inne projekty opierające się na partycypacji społecznej najczęściej kierowane są do dzieci i młodzieży, po to aby kształtować $\mathrm{w}$ nich postawy proobywatelskie, na przyszłość.

Jak już wspomniano, głównym celem podejmowanych w sferze publicznej działań wykorzystujących założenia koncepcji crowdsourcingu jest skuteczne włączenie społeczności w proces decyzyjny, uzyskanie akceptacji dla podejmowanych działań i budowanie zaufania społecznego. Aby osiągnąc tak sformułowany cel, muszą zaistnieć odpowiednie warunki. Na rysunku 1 przedstawiono model czynników, które determinują poziom zaangażowania obywatelskiego i wpływają na efektywność przedsięwzięć w przestrzeni publicznej opartych na crowdsourcingu. Model ten ujmuje czynniki wpływające na stopień zaangażowania społecznego w projektach publicznych, których mechanizm realizacji opiera się na założeniach koncepcji crowdsourcingu. Konstrukcja przedstawionego modelu czerpie z przeanalizowanych koncepcji zaangażowania organizacyjnego [Mowday i in., 1982; O’Reilly, Chatman, 1986; Allen, Meyer, 1990] oraz modeli zaangażowania w koncepcji crowdsourcingu [Cupido, Ophoff, 2014].

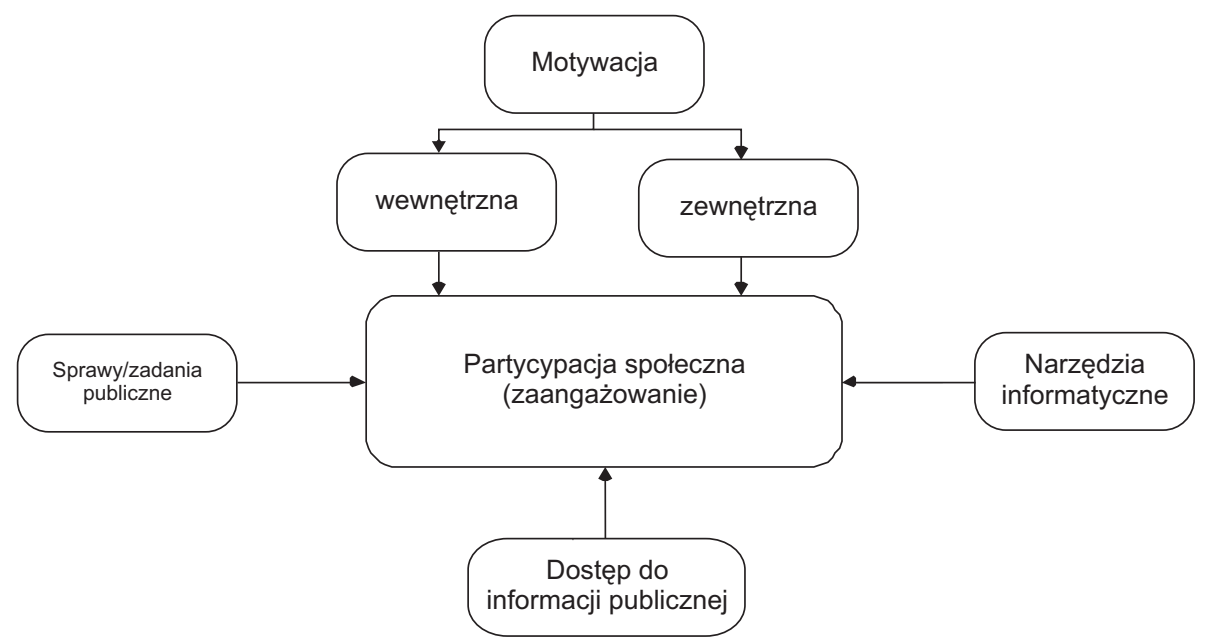

Rysunek 1. Krytyczne czynniki sukcesu dla inicjatyw władz państwowych realizowanych z wykorzystaniem crowdsourcingu

Źródło: opracowanie własne na podstawie Cupido, Ophoff, 2014.

Zgodnie z przedstawionym schematem, aby inicjatywy w sferze publicznej oparte na crowdsourcingu przyniosły zamierzone efekty, muszą zostać spełnione odpowiednie warunki. Aktywne partycypowanie społeczeństwa w proces zarządzania sprawami publicznymi zależy od: 
- odpowiedniego zdefiniowania, przedstawienia problemu kierowanego do społeczeństwa,

- przyjętej strategii realizacji inicjatyw publicznych oraz kontroli ich przebiegu na każdym etapie wykonania,

- dostępu do informacji publicznej,

- wykorzystywanych narzędzi informatycznych,

- potrzeby działania wynikającej z motywacji.

Wszystkie zaprezentowane na rysunku 1 czynniki wpływają na poziom partycypacji społecznej i wzajemnie się przenikają.

\section{I. Inicjatywy publiczne - strategia realizacji}

Każda inicjatywa publiczna realizowana za pomocą crowdsourcingu wymaga od władz publicznych przyjęcia strategii działania. Strategia definiuje cele, przypisuje im działania, monitoruje i zarządza procesem. Zgodnie z dotychczasową praktyką realizacja tego typu inicjatyw przebiega fazowo. Każdy etap powinien zostać ujęty w ramy czasowe. $\mathrm{W}$ tabeli 1 przedstawiono fazy realizacji zadań publicznych opartych na koncepcji crowdsourcingu.

Tabela 1

Etapy realizacji inicjatyw publicznych opartych na crowdsourcingu

\begin{tabular}{|c|c|c|}
\hline $\begin{array}{l}\text { Etapy w procesie realizacji spraw/ } \\
\text { zadań publicznych }\end{array}$ & Krótka charakterystyka etapów & \\
\hline $\begin{array}{l}\text { Etap wstępny - przygotowanie } \\
\text { założeń }\end{array}$ & $\begin{array}{l}\text { - zdefiniowanie celów inicjatywy } \\
\text { - ustalenie poziomu administracyjnego, na którym } \\
\text { będzie realizowana } \\
\text { - określenie „aktorów” inicjatywy }\end{array}$ & $\mathrm{M}$ \\
\hline $\begin{array}{l}\text { Etap I - określenie zasad realizacji } \\
\text { inicjatywy }\end{array}$ & $\begin{array}{l}\text { - powołanie zespołu realizującego inicjatywę } \\
\text { - określenie zasad i regulaminu realizacji inicjatywy }\end{array}$ & $N$ \\
\hline $\begin{array}{l}\text { Etap II - przeprowadzenie akcji } \\
\text { informacyjno-edukacyjnej }\end{array}$ & - wybór kanałów i materiałów informacyjnych & $\mathrm{O}$ \\
\hline $\begin{array}{l}\text { Etap III - zgłaszanie projektów/ } \\
\text { rozwiązań }\end{array}$ & $\begin{array}{l}\text { - bieżące śledzenie zgłaszanych propozycji, uwag } \\
\text { i wskazówek }\end{array}$ & $\begin{array}{l}\text { R } \\
\mathrm{I} \\
\mathrm{N}\end{array}$ \\
\hline $\begin{array}{l}\text { Etap IV - weryfikacja projektów/ } \\
\text { rozwiązań i dyskusja nad nimi }\end{array}$ & $\begin{array}{l}\text { - weryfikacja na podstawie realizacji przyjętych } \\
\text { celów inicjatywy }\end{array}$ & G \\
\hline Etap V - wybór projektów/rozwiązań & $\begin{array}{l}\text { - zgodnie z przyjętym regulaminem } \\
\text { (np. głosowanie) }\end{array}$ & \\
\hline $\begin{array}{l}\text { Etap VI - kompleksowa ocena skut- } \\
\text { ków przeprowadzanych inicjatyw }\end{array}$ & $\begin{array}{l}\text { - kontrola bieżąca realizacji wybranych projektów } \\
\text { - ocena na poziomie realizowanych etapów (ocena } \\
\text { zastosowanych rozwiązań, metod, narzędzi) i na } \\
\text { poziomie zrealizowanych celów }\end{array}$ & \\
\hline
\end{tabular}

Źródło: opracowanie własne na podstawie Standardy..., 2015. 
W projektach inicjowanych przez władze publiczne cele powinny zostać ściśle określone i przyjęte na wstępnym etapie procesu. Nadrzędnym celem w inicjatywach społecznych jest włączenie społeczności w proces decyzyjny. Skoro celem cząstkowym jest efektywne wydawanie środków publicznych, to realizowane powinny być te projekty, które służą jak największej grupie członków społeczności lokalnej, a nie te, które realizują potrzeby grupy wąskiej, ale dobrze zorganizowanej. Poza zdefiniowaniem celów ustala się, na jakim poziomie administracyjnym i w jakiej kwocie projekt będzie realizowany. Każdy kolejny etap powinien być wprowadzany w życie w sposób, który gwarantuje osiągnięcie przyjętych celów.

Komunikowanie się ze społeczeństwem opiera się na przekazywaniu informacji. Zaangażowanie obywatelskie, o które zabiega władza, będzie zależało od zrozumienia i interpretowania komunikatów przez społeczność. Nawet w najlepiej zaplanowanym i przeprowadzanym projekcie, którego podstawą jest komunikacja, dochodzi do pewnych deformacji przekazywanych informacji. Chodzi o różnice w percepcji, wynikające z różnicy intelektualnej, wieku, płci, zawodu czy pozycji społecznej uczestników komunikacji. Aby osłabić możliwe zakłócenia w odbiorze, informacja musi zostać „skrojona” pod adresata. Zazwyczaj wybieranym kanałem komunikacji w inicjatywach crowdsourcingowych jest internet, ale przekaz informacji poszerza się o inne możliwe kanały, takie jak ulotki, spoty informacyjne w mediach lokalnych, spotkania informacyjne itd. Cały proces zarządzania określonym zadaniem (sprawą) publicznym wymaga ciągłego monitoringu. To oznacza, że społeczność, której projekt dotyczy, ma dostęp do informacji o jego przebiegu na każdym etapie, również po wybraniu projektu i przekazaniu go do realizacji urzędnikom.

Przyjęta strategia realizacji zadania publicznego powinna obejmować zestaw zasad i wartości, które gwarantują faktyczne współdecydowanie obywateli. W sferze spraw publicznych wykorzystujących mechanizm crowdsourcingu tymi kluczowymi zasadami są:

- wiążący wynik procedury,

- przejrzystość i jawność procedur,

- otwartość i inkluzywność procesu,

- zapewnienie przestrzeni do debaty z mieszkańcami,

- wspieranie aktywności mieszkańców,

- myślenie strategiczne o realizowanych projektach [Standardy..., 2015].

Zaangażowanie obywateli, danej społeczności w realizację zadań wskazanych przez władze publiczne może zależeć od charakteru zadania. Jeśli jest ono proste, nie wymaga znaczącego wysiłku intelektualnego i sprowadza się np. do głosowania, to można założyć, że znaczna grupa społeczna zaangażuje się w taki projekt. W sytuacji gdy zadanie wymaga wiedzy, czasu i opracowania rozwiązania, poziom partycypacji społecznej może być niski. 


\subsection{Motywacja}

Efektywność przedsięwzięć crowdsourcingowych typu budżet obywatelski, procesy ustawodawcze czy plany urbanistyczne zależy od tego, ile wysiłku i czasu poświęcimy tego typu zadaniom. Człowiek, angażując się w rozwiązywanie problemów lub zadań, z upływem czasu ma tendencję do minimalizowania wysiłku [Todd, Benbasat, 1991]. Zadania i sprawy publiczne kierowane do społeczeństwa powinny przyjmować krótki horyzont czasowy. Zbyt długi czas realizacji projektu grozi stopniową utratą chęci i zainteresowania obywateli.

Zaangażowanie lokalnej społeczności w projekty oparte na crowdsourcingu zależy od tego, na ile jej członkowie są zmotywowani do działania w sferze publicznej. Zgodnie $\mathrm{z}$ modelem samodeterminacji $\mathrm{w}$ inicjatywach crowdsourcingowych wyróżnia się motywacje wewnętrzną i zewnętrzną. Zaangażowanie obywatelskie kształtuje przede wszystkim motywacja wewnętrzna, a ta w znacznym stopniu wynika z cech osobowości, takich jak potrzeba przynależności do grupy, kierowanie się potrzebami wyższego rzędu czy ekstrawersja. Na naszą chęć do działania w sferze publicznej mają wpływ uwarunkowania kulturowe. W Polsce poziom zaufania do władz publicznych był i jest niski. Oznacza to, że wysiłki państwa powinny mieć na celu zmianę postawy społeczeństwa wobec działań państwa, a to jest możliwe, jeśli realizowane są zasady i działa się w zgodzie z wartościami decydującymi o faktycznym współdecydowaniu obywateli - przedstawiono je w punkcie 2.1.

Inicjatywy społeczne realizowane $\mathrm{z}$ wykorzystaniem koncepcji crowdsourcingu mają dwóch aktorów: organizację (władzę publiczną na różnym szczeblu) i społeczeństwo. Jak już wspomniano, zaangażowanie obywateli do działania na rzecz spraw publicznych wynika przede wszystkim z realizowanych przez nich potrzeb wewnętrznych. Niemniej poziom partycypacji społecznej zależy również od motywacji władz publicznych, od urzędników.

\subsection{Dostęp do informacji publicznej}

Społeczeństwo informacyjne to takie, które ma otwarty i pełny dostęp do informacji publicznej. W praktyce oznacza to łatwy i nieograniczony dostęp obywatela do opracowań i dokumentów generowanych przez instytucje publiczne. Jest to dzisiaj możliwe dzięki intensywnemu rozwojowi technologii cyfrowych. Wykorzystywane w administracji państwowej nowoczesne technologie informatyczne, a szerzej informacyjne, poprawiają jej efektywność. Wypracowany proces generowania informacji w administracji publicznej, czyli tworzenia, prezentowania i archiwizacji informacji, daje obywatelom możliwość weryfikowania treści, opiniowania i porównywania. Warunkuje realizację celów administracji państwowej w zakresie angażowania obywateli w życie publiczne, uczenia demokracji i wspólnej odpowiedzialności na zarządzanie państwem. Czynnik dostępu do informacji jest powiązany z kolejnym czynnikiem, określonym jako narzędzia informatyczne. 


\subsection{Narzędzia informatyczne}

Współczesne społeczeństwo, jak nigdy wcześniej, ma właściwie nieograniczony dostęp do narzędzi, dzięki którym odbiera informacje z zewnątrz. Informacje i komunikaty adresowane przez władze publiczne do obywateli najczęściej są przekazywane drogą elektroniczną. Powinny być prezentowane w programach komputerowych, a dokładnie w plikach, których otwarcie jest możliwie dla każdego użytkownika. Chodzi o wyeliminowanie barier informatycznych, które mogą ograniczać współuczestniczenie w procesach zarządzania.

\section{Podsumowanie}

Od kilku lat rośnie zainteresowanie inicjatywami społecznymi, których implementacja powinna prowadzić do wzrostu zaangażowania obywateli w sprawy publiczne i w sposób długofalowy budować więź społeczną. Realizacja tego typu inicjatyw podejmowanych przez państwo opiera się często na wykorzystaniu założeń koncepcji crowdsourcingu. Władze na różnym szczeblu, stosując zazwyczaj platformę internetową, kierują do społeczeństwa zadania bądź problemy do rozwiązania i otrzymują informację zwrotną w postaci uwag, pomysłów i opinii wyrażonych przez wskazane środowisko.

Rezultatem poprawnie przeprowadzonych działań w sferze publicznej jest wzrost zaufania do władz i kształtowanie trwałej demokracji partycypacyjnej. Przedstawiony w artykule model czynników, które wpływają na poziom zaangażowania obywateli w sprawy danej społeczności, został odniesiony do dotychczasowych polskich doświadczeń. Liczne raporty organizacji społecznych zajmujących się analizą wdrażanych w Polsce inicjatyw opartych na mechanizmie crowdsourcingu w sektorze publicznym [Młynarski i in., 2013; Standardy..., 2015; Skrzypiec i in., 2016] potwierdzają, że wskazane w modelu czynniki kształtują poziom zaangażowania społecznego. To od motywacji, strategii realizacji, dostępu do informacji i narzędzi komunikacji zależy poziom aktywizacji społeczności do działania na rzecz wspólnych spraw. Szczególnie słabym ogniwem w procesie budowania powszechnego zaangażowania społecznego jest sposób przygotowania, a następnie realizacji działań publicznych. W podejmowanych inicjatywach można wskazać niedociągnięcia i błędy właściwie na każdym etapie ich realizacji. Pozostałe czynniki wpływające na zaangażowanie obywateli też wymagają poprawy. To, co dzisiaj osłabia partycypację społeczną, to:

- brak wystarczającego wsparcia finansowego dla organizacji pozarządowych, które pełnią funkcję łącznika między władzą a społeczeństwem;

- realizowanie tylko jednej inicjatywy społecznej, często budżetu partycypacyjnego;

- brak zaufania do władz na każdym poziomie administracyjnym; 
- brak dyskusji, wyznaczania priorytetowych potrzeb na poziomie danej grupy społecznej;

- wykluczanie pewnych grup społecznych w danej wspólnocie lokalnej (np. przez brak dostępu do internetu lub brak umiejętności posługiwania się nim);

- brak oceny realizacji projektów, ich etapów, stopnia realizacji celów;

- przystępowanie do kolejnych inicjatyw bez oceny i wyciągnięcia wniosków z wcześniej zakończonych.

Władze publiczne chętnie proponują narzędzia umacniające demokrację partycypacyjną, ale rezultaty są niezadowalające. Nie realizujemy najważniejszych celów otwartej polityki władz publicznych. Nie wrasta zaufanie obywateli do działań przeprowadzanych przez te władze i nie rośnie poziom ich zaangażowania w sprawy wspólne, dotyczące społeczności, którą reprezentują [CBOS, 2013; CBOS, 2016; TNS, 2016].

\section{Bibliografia}

Adams, S.A. (2011), Sourcing the Crowd for Health Services Improvement: The Reflexive Patient and 'Share-Your-Experience' Websites, ,Social Science \& Medicine”, 72(7).

Allen N.J., Meyer J.P. (1990), The Measurement and Antecedents of Affective, Continuance and Normative Commitment to the Organization, ,Journal of Occupational Psychology”, 63(1).

Arnold U. (2000), New Dimensions of Outsourcing: A Combination of Transaction Cost Economics and the Core Competencies Concept, „European Journal of Purchasing \& Supply Management", 6(1).

Brabham D.C. (2009), Crowdsourcing the Public Participation Process for Planning Projects, „Planning Theory”, 8(3).

Brabham D.C. (2010), Moving the Crowd at Threadless: Motivations for Participation in a Crowdsourcing Application, „Information, Communication \& Society”, 13(8).

Brabham D.C. (2012), Motivations for Participation in a Crwodsurcing Application to Improve Public Engagement in Transit Planning, ,Journal of Applied Communication Research", 40(3).

Brabham D.C. (2013), Crowdsourcing, The MIT Press, Cambridge (Mass.)-London.

Bugs G., Granell C., Fonts O., Huerta J., Painho M. (2010), An Assessment of Public Participation GIS and Web 2.0 Technologies in Urban Planning Practice in Canela, Brazil, „Cities”, 27(3).

CBOS [Centrum Badania Opinii Społecznej] (2013), Poczucie wptywu na sprawy publiczne, http://www.cbos.pl/SPISKOM.POL/2013/K_121_13.PDF [dostęp: 10.10.2017].

CBOS [Centrum Badania Opinii Społecznej] (2016), Zaufanie społeczne, http://www.cbos.pl/ SPISKOM.POL/2016/K_018_16.PDF [dostęp: 10.10.2017].

Cupido K., Ophoff J. (2014), A Model of Fundamental Components for an e-Government Crowdsourcing Platform, ,Electronic Journal of e-Government” 12(2).

Deci E.L., Ryan R.M. (1991), A Motivational Approach to Self: Integration in Personality, „Perspectives on Motivation”, 38. 
Estellés-Arolas E., González Ladrón-de-Guevara F. (2012), Towards an Integrated Crowdsourcing Definitione, ,Journal of Information Science”, 38(2).

Hilgers D., Ihl C. (2010), Citizensourcing: Applying the Concept of Open Innovation to the Public Sector, „International Journal of Public Participation”, 4(1).

Howe J. (2006), The Rise of Crowdsourcing, „Wired Magazine”, 14(6).

Jain R. (2010), Investigation of Governance Mechanisma for Crowdsourcing Initiatives, Americas Conference on Information Systems (AMCIS), 557, http://aisel.aisnet.org/amcis2010/557 [dostęp: 10.09.2017].

McIvor, R. (2010), Global Services Outsourcing, Cambridge University Press, New York.

Marcinkowska E. (2012), Outsourcing w zarzqdzaniu szpitalem publicznym, Wolters Kluwer, Warszawa.

MłynarskiG., TarkowskiA.,JachowiczŁ.(2013), OtwartyRzadwPolsce.KulisyprogramuOpenGov, Centrum Cyfrowe Projekt: Polska, Warszawa, https://centrumcyfrowe.pl/wp-content/uploads/2013/06/Otwarty-rzad-w-Polsce-Publikacja-OPENGOV-v1-0.pdf [dostęp: 20.09.2017].

Mowday R.T., Porter L., Steers R.H. (1982), Employee-Organization Linkages, the Psychology of Commitment, Absenteeism and Turnover, Academic Press, London.

Open Government Initiative, https://obamawhitehouse.archives.gov/open [dostęp: 2.09.2017].

O'Reilly C.A., Chatman J. (1986), Organizational Commitment and Psychological Attachment: The Effects of Compliance, Identification and Internalization on Prosocial Behavior, „Journal of Applied Psychology", 71(3).

Prpić J., Shukla P., Kietzmann J., McCarthy I. (2015), How to Work a Crowd: Developing Crowd Capital Through Crowdsourcing, „Business Horizons”, 58(1).

Ryan R.M., Deci E.L. (2000), Self-Determination Theory and the Facilitation of Intrinsic Motivation, Social Deveplment, and Well-Being, „Amercian Psychologist”, 55(1).

Skinner B.F. (1953), Science and Human Behavior, The Free Press, New York.

Skrzypiec R., Wyszomirski P., Wójkowski G. (2016), Skontroluj, jak działa budżet obywatelski w twojej gminie. Raport końcowy, Stowarzyszenie Aktywności Obywatelskiej Bona Fides, Katowice, www.bonafides.pl/wp-content/uploads/2016/.../budzet_obywatelski-raport_18_jst.pdf [dostęp: 20.09.2017].

Standardy procesów budżetu partycypacyjnego w Polsce (2015), Fundacja Pracownia Badań i Innowacji Społecznych „Stocznia”, Warszawa, http://partycypacjaobywatelska.pl/ wp-content/uploads/2014/06/broszura-budzety-partycypacyjne.pdf [dostęp: 10.09.2017].

Stewart O., Lubensky D., Huerta J.M. (2010), Crowdsourcing Participation Inequality: A SCOUT Model for the Enterprise Domain, Proceedings of the ACM SIGKDD Workshop on Human Computation, ACM, New York.

TNS [Zespół Badań Społecznych TNS Polska] (2016), Zaufanie do instytucji publicznych, http://www.tnsglobal.pl/archiwumraportow/files/2016/11/K.068_Zaufanie_do_instytucji_O10a-16.pdf [dostęp: 10.10.2017].

Todd P., Benbasat I. (1991), An Experimental Investigation of the Impact of Computer Based Decision Aids on Decison Making Processes, „Information Systems Research”, 2. 